\title{
A Study of Mission Statements Among LARGE U. S. MANUFACTURERS
}

\author{
Fred R. David \\ College of Business Administration \\ Auburn University \\ Auburn, Alabama \\ Daniel S. Cochran \\ College of Business and Industry \\ Mississippi State University \\ Mississippi State, Mississippi
}

An increasing number of organizations around the world are developing a formal mission statement as part of the strategic management process. A mission statement reveals the long-term vision of an organization in terms of what it wants to be and who it wants to serve. A clear mission statement answers a key question about an enterprise: "What is our Business?" A good answer to this question makes strategy formulation, strategy implementation, and strategy evaluation activities much easier. Sometimes called a statement of purpose, philosophy, or creed, a mission statement is increasingly being perceived among firms as indication of strategic management sophistication [8]. The importance of a mission statement to effective strategic management is recognized by many practitioners, but considerable diversity and confusion exists regarding the composition of these documents. The present study was thus undertaken to examine the content of corporate mission statements. Based on the findings, this paper offers suggestions for writing a corporate mission statement.

\section{Literature Review}

A mission statement should define what an organization is and what it aspires to be ([4], [9]). Mission statements should be limited enough to exclude some ventures and be broad enough to allow for creative growth. A mission document should distinguish a particular organization from all others and should serve as a framework for evaluation both current and prospective activities [8]. Mission statements should be stated in terms sufficiently clear to be widely understood throughout the organization. An example mission statement for Eli Lilly and company is given below:

Journal of Business Strategies, Volume 4, Number 2 (Fall 1987) 
Eli Lilly and Company is a research-based corporation that develops, manufactures, and markets human medicines, medical instrument systems, diagnostic products, agricultural products, and cosmetics. To guide its affairs, the company follows certain fundamental principles. These principles, which we believe are in the best long-term interests of all shareholders, are the following: The company is committed to the discovery and marketing of innovative products of the highest quality that offer benefits to customers in all of our markets. The company is dedicated to the highest levels of ethics, integrity, and excellence in research, manufacturing, marketing, and all other phases of its operations. The company recognizes primary responsibility to its employees because of the key role employees play in the achievement of corporate goals. The company's objective is to attract and retain outstanding people at all levels and in all parts of the organization. It is committed to fair and equitable treatment of all employees and to policies and programs that offer the opportunity for employees to develop meaningful and rewarding careers. The company feels an obligation to be a good corporate citizen wherever it operates.

Previous studies reveal eight components that are important for inclusion in a mission statement $([3],[7])$. Subsequently called literature-derived components in this paper, these variables are "customers," "products or services," "location," "technology," "concern for survival, growth, and profits," "philosophy," "self-concept," and "concern for public image." Pearce [7] indicates that "products or services," "location," and "customer" are especially important components. Want [9] concludes that "customer," "products or services," "concern for survival, growth, and profitability," "philosophy," and "concern for public image" as the most important components. Drucker [4] suggests that the "customer" component is most important for inclusion in a mission statement. Although a number of conceptual articles and business policy texts [2] discuss mission statements, the composition of mission statements varies among different types of firms. More information is needed to assist practitioners charged with developing a formal mission statement.

All organizations have a reason for being, even if top managers have not consciously transformed this into a written document. A clear and meaningful mission statement can ensure unanimity of purpose within an organization, can provide a basis for motivating the use of organizational resources, can develop organizational climate. A mission statement is often the most visible and public part of a strategic plan [6]. As such, an enterprise should insure that its statement of mission clearly communicates appropriate information to guide and motivate employees, customers, shareholders, and other constituencies. 


\section{Methodology}

\section{The Sample}

A personal letter was mailed to the chief executive officers of all Fortune 500 manufacturing firms in the United States. The letter requested a copy of the organization's formal mission statement. A mission statement was defined as "an enduring statement of purpose that reveals an organization's product or service, markets, customers, and philosophy; a mission statement is sometimes referred to as a statement of purpose, philosophy, or creed." Responses were received from 218 firms, representing an overall 44 percent response rate. Among the responding firms, 88 corporations had not prepared a mission statement, but 130 firms said they did have a mission statement. Among the 130 firms, 11 corporations replied that their mission statement was confidential and they could not send us a copy. There were 58 firms which sent material such as an annual report that did not clearly include a formal mission statement. Finally, 61 of the 130 firms provided a usable mission statement that was evaluated using content analysis.

\section{The Hypothesis}

Type of industry is an important contingency variable in strategic management research. A recent empirical study of PIMS program data revealed that type of industry (industrial versus consumer products forms) was the most important contingency variable in business strategy [5]. It was hypothesized in this study that the mission statements of industrial products firms would include a different mix of literature-derived components than mission statements of consumer products firms. Among the 61 sample firms, there were 27 consumer products companies and 34 industrial products companies. Ten of the consumer products firms were in the food industry and six industrial products companies manufactured farm equipment.

The investigation of this hypothesis was justified from the growing evidence that consumer and industrial firms are different in many ways that impact strategy decisions. Specifically, consumer products firms produce goods that are marketed directly to individuals through various types of retail organizations. Consumer goods include items such as tobacco products, soap, newspapers, furniture, clothing, used cars, major appliances, photographic equipment, men's suits, life insurance, cemetery plots, gravestones and encyclopedias. Consumer products are often categorized as convenience goods, shopping goods, and specialty goods. On the other hand, industrial products include items such as farm products, petroleum products, pig iron, yarn, generators, drill presses, elevators, lift trucks and office equipment. Industrial goods are often categorized as materials and parts, capital equipment, and supplies and services.

Industrial products firms differ significantly from consumer products firms in their strategic attributes and performance [5]. The competitive environment and primary policy areas differ significantly according to user sector. For 
example, R\&D personnel and engineers are frequently the strategy decisionmakers in industrial products firms, whereas marketing managers are generally the primary decision-makers in consumer products firms. Industrial products firms stress a different facet of competitive strategy compared to the consumer products firms. Industrial markets have certain unique characteristics, such as fewer and larger buyers, graphically concentrated buyers, and derived demand. Industrial products firms differ significantly from consumer products firms in their competitive intelligence-gathering efforts. Industrial products firms more often gather information for offensive rather than defensive purposes [5].

\section{Measures}

Content analysis can be used to develop, write, and evaluate mission statement documents [1]. In the present study, two independent raters read the sample mission statements and recorded whether or not each statement included the literature-derived components. If a mission statement was judged as exhibiting a particular component, the rater recorded a value of "1" to the statement for that component. When a particular mission statement did not "clearly" exhibit a literature-derived component, a " 0 " was assigned to the statement for that component. The eight mission statement components were operationalized systematically whereby each rater independently asked the following key questions about each document:

1. Customer - Does the mission statement identify the firm's major customers?

2. Product or service - Does the mission statement identify the firm's major products or services?

3. Location - Does the mission statement identify the location of the firm's business markets?

4. Technology - Does the mission statement identify the firm's basic technology?

5. Concern for survival, growth, and profits - Does the mission statement reveal that the firm is concerned about survival, growth, and profitability?

6. Philosophy - Does the mission statement reveal the firm's basic beliefs, values, aspirations, and philosophical priorities?

7. Self-concept - Does the mission statement reveal the firm's competitive advantages and major strengths?

8. Concern for public image - Does the mission statement reveal that the firm is concerned about its public image? 
Interrater reliability coefficients revealed no significant differences between the two independent raters' scores. The computed Chi-square value of 3.73 indicated no significant difference between the two raters on their evaluation of the mission statements. The critical Chi-square value was 21.67 at the .01 level of significance and nine degrees of freedom. Some degree of subjectivity is always involved in evaluating written documents using content analysis, so the present raters studied mission statement articles and documents carefully before beginning the evaluation process.

\section{The Results}

Parametric $t$-test analyses were used to test the hypothesis that mission statements of industrial products firms include a different mix of literaturederived components than the mission statements of consumer products firms. As indicated in Table 1, the mission statements of industrial products firms include the "product" component significantly more often than the mission statements of consumer products firms ( 76 percent of the time compared to 56 percent of the time). In addition, 29 percent of the mission statements of industrial products firms include the "technology" component, compared to 8 percent of the mission statements of consumer products firms. This difference was also statistically significant. The mission statements of industrial products firms more often include the "customer," "location," "concern for survival, growth, and profits," and "self-concept" components as indicated

Table 1

Comparing Mission Statements of Consumer Products Firms and Industrial Products Firms $(n=61)$

\begin{tabular}{|l|lc|cc|c|}
\hline & \multicolumn{2}{|c|}{$\begin{array}{c}\text { Consumer Products } \\
\text { Firms }(n=26)\end{array}$} & \multicolumn{2}{|c|}{ Industrial Products } & \\
\hline \hline Variable & Mean & $s^{a}$ & Mean & $s$ & $t$-value \\
\hline Customer & .4400 & .507 & .5000 & .508 & -0.45 \\
Product or Service & .5600 & .507 & .7647 & .431 & $-1.63^{* b}$ \\
Location & .3200 & .476 & .4412 & .504 & -0.94 \\
Technology & .0800 & .277 & .2941 & .462 & $-2.21^{* * c}$ \\
Concern for & & & & & \\
Survival, Growth, & & & & & \\
and Profits & .8800 & .332 & .9412 & .239 & -0.78 \\
Philosophy & .8800 & .332 & .7353 & .448 & +1.43 \\
Self-Concept & .7200 & .458 & .8235 & .387 & -0.91 \\
Public Image & .9200 & .277 & .8235 & .387 & +1.12 \\
\hline
\end{tabular}

$a_{s}=$ sample standard deviation

b* $\rho<.10$

c* $\rho<.05$ 
by higher mean values. These results support the hypothesis that the mission statements of industrial products firms include a different mix of literaturederived components than the mission statements of consumer products firms.

\section{Discussion}

\section{Implications for Practitioners}

It should be noted initially that this study did not examine organizational performance or effectiveness. Hence, no conclusions can be made regarding whether more articulate mission statements impact organizational performance or effectiveness in a positive or negative way. Prior research does suggest that comprehensive mission statements impact organizational performance positively, but this study did not examine that hypothesis $([3],[8])$.

In this study, the mean values associated with industrial products firms are higher than the mean values associated with consumer products firms on all variables except "philosophy" and "concern for public image." Thus, industrial products firms appear to prepare a more comprehensive mission statement than consumer products firms. This finding could indicate that top managers of consumer products firms especially need to review their mission statement document to assure that it includes desired components and communicates the desired message.

The low percentage values of 8,32 , and 44 for consumer products firms and 29,44 , and 50 for industrial products firms indicate that large U.S. manufacturers overall tend not to include the "technology," "location," and "customer" components respectively when developing a mission statement document. First, technology changes are shortening the product life cycle in nearly all industries, so this finding suggests that large U.S. manufacturers may not adequately be considering technological opportunities and threats in formulating and implementing strategies. Improvement could especially be warranted among consumer products firms which on average include "technology" only eight percent of the time in a mission statement. Second, large U.S. manufacturers should consider including geographic "location" more often in developing a mission statement document because foreign manufacturers are gaining an increasing market share in many industries. Third and perhaps most important is the need for large U.S. corporations to more often include "customers" in developing a formal mission statement. Customers are what give meaning to any business organization.

\section{Writing a Mission Statement}

The key questions outlined in the measures section of this paper provide a basis for writing a formal mission statement. The mission statement for Mary Kay Cosmetics, an international, consumer products firm, is given in Figure 1. Mary Kay Cosmetics' mission statement was judged by both independent raters in this study as including all eight literature-derived components. The actual evaluative process for the Mary Kay statement is described here to aid 
practitioners in developing a mission statement. First, the Mary Kay document reveals the firm's "customers" to be women. The company's "product" is a "personalized skin care regimen." Mary Kay's "location" or geographic area for business is the world. Mary Kay's "technology" is based on "quality assurance and research." The company's "concern for survival and growth" is evident since the statement describes the desire for "high productivity" and "growth of the company." The company's "philosophy" is "based on the golden rule." Mary Kay's "self-concept" and desired "public image" is to be the "finest teaching-oriented skin care organization in the world."

Figure 1

\section{Mary Kay Cosmetics' Mission Statement}

\section{Mary Kay Cosmetics}

Choices. A woman's life is filled with them. Her busy world demands choices about how she uses her time, juggles her commitments and reaches her goals. But whatever her lifestyle, Mary Kay is right for the times.

Because we understand a woman's needs and care about meeting them. We do more than just sell a woman cosmetics. We teach a personalized skin-care regimen, help her discover her own glamour look, and provide continuing service to assure that her skin care and beauty programs stay consistent with her changing needs.

Our corporate goal for the 1980's is to be the finest teachingoriented skin-care organization in the world. We're doing that by teaching women about their skin and how to care for it. Our program is based on a personal relationship with an individual Beauty Consultant, who guides, instructs, and counsels each of her clients.

Women appreciate the service and knowledge they get from their Mary Kay Beauty Consultant. Our careful quality assurance and research means we're so confident about our products that we offer a 100 percent satisfaction guarantee.

We can do this because Mary Kay understands the way women want to look and live, offering products and services to meet their needs in the '80s. Equally important, we care about our customers-and make sure they know it. Because customers don't care how much we know until they know how much we care.

It's all part of the Mary Kay philosophy-a philosophy based on the golden rule. A spirit of sharing and caring where people give cheerfully of their time, knowledge, and experience.

Our management believes strongly in human resources. Excellent compensation, recognition, opportunity for growth, and pride motivate our employees, as well as 196,755 independent Beauty 
Consultants. A key element in the Mary Kay success equation is the Company's organizational structure which stimulates individual and group creativity, communication, and performance. This results in a high level of personal satisfaction, which in turn is reflected in high productivity.

This success-oriented attitude leads everyone to new heights and greater achievements. Achievements which are based on discipline and determination, and mean growth for each individual as well as the Company. (Source: Mary Kay Cosmetics, Annual Report, 1982, p.5)

\section{Conclusions}

Developing an effective mission statement is a primary responsibility of chief executive officers. Many practitioners recognize mission statements as an important strategic management tool, but published research on mission statements is limited. Additional studies are needed before general recommendations can be made regarding the composition of mission statement documents. Profiles of the mission statements of high performing firms versus low performing firms need to be developed by size of firm and type of industry. The present study provides insight to managers who may be in the process of developing, writing, and evaluating a formal mission statement. Specific components to include in writing a mission statement are exemplified through the Mary Kay Cosmetics document.

The results of this study provide a basis for devising and investigating future research hypotheses to extend management's understanding of the relationship betwen mission statements and other organizational variables. The relationship between mission statements and organizational development, employee motivation, communication systems, and social responsibility needs examination. Differences between the composition and intent of business unit and corporate mission statements should be explored. Further research could determine particularly effective uses of mission statements. Additional information regarding mission statements could allow these documents to become an effective tool for improving corporate performance.

\section{References}

1. Cochran, D.S., F.R. David, and C.K. Gibson. "A Framework for Developing an Effective Mission Statement." Journal of Business Strategies, vol. 2, no. 1, Fall 1985, pp. 4-17.

2. David, F.R. Fundamentals of Strategic Management. Columbus, OH: Merrill Publishing Company, 1986.

3. David, F.R. and Cochran, D.S. "Mission Statements: An Important Strategic Tool." Long Range Planning, 1987 (in press). 
4. Drucker, P. Management: Tasks, Responsibilities, and Practices. New York, NY: Harper \& Row, Publishers, 1974.

5. Hambrick, D.C. and Lei, D. "Toward an Empirical Prioritization of Contingency Variables for Business Strategy." Academy of Management Journal, vol. 28, no. 4, December 1985, pp. 763-788.

6. McGinnis, V.J. "The Mission Statement: A Key Step in Strategic Planning." Business, November-December 1981, pp. 39-43.

7. Pearce, J.A., II. "The Company Mission as a Strategic Tool." Sloan Management Review, Spring 1982, pp. 15-24.

8. Pearce, J.A., II and David, F.R. "Corporate Mission Statements: The Bottom Line." Academy of Management Executive, vol. 1, no. 2, May 1987, pp. 109-116.

9. Want, J.H. "Corporate Mission: The Intangible Contributor to Performance." Management Review, August 1986, pp. 46-50. 